\title{
Combinations of AMPA Receptor Subunit Expression in Individual Cortical Neurons Correlate with Expression of Specific Calcium- Binding Proteins
}

\author{
Masahiro Kondo, ${ }^{1,2}$ Rhyuji Sumino, ${ }^{2}$ and Haruo Okado ${ }^{1}$ \\ ${ }^{1}$ Department of Neurobiology, Tokyo Metropolitan Institute for Neuroscience, Fuchu, Tokyo 183, Japan, and ${ }^{2}$ Department \\ of Physiology, School of Dentistry, Nihon University, Chiyoda 101, Japan
}

The functional properties of AMPA-type glutamate receptors are determined by their subunit composition. We detected the expression of the AMPA receptor subunits (GluR1-GluR4) in neurons in the somatosensory cortex of adult rats by combining nonradioactive in situ hybridization using digoxigenin-labeled RNA probes of GluR1 and GluR2 with immunocytochemistry using specific antibodies against GluR1, GluR2/3, and GluR4. On the basis of differential expression of the GluR1 and GluR2 subunits, we classified the cortical neurons into four categories. To correlate the differential expression of AMPA receptor subunits in each neuron with that of two calcium-binding proteins, parvalbumin and calbindin-D28k, we used a triple-labeling method. The majority of cortical neurons ( 2/3) showed expression of GluR2 and undetectable expression of GluR1. GluR1-/GluR2-expressing neurons and GluR1-expressing/GluR2-undetectable neurons comprised $\sim 1 / 10$ each. Regarding the morphology, most GluR1-
undetectable/GluR2-expressing neurons were pyramidal cells in layers II/II, V, and VI, whereas most GluR1-expressing/GluR2undetectable neurons were nonpyramidal cells in layers II-VI. The GluR1-/GluR2-expressing neurons were either pyramidal or nonpyramidal. The majority of GluR1-/GluR2-expressing nonpyramidal cells was intensely stained with monoclonal antibody against calbindin-D28k, and one-half of the GluR1-undetectable/GluR2expressing pyramidal neurons in layer II/III were lightly stained with this antibody. Most of GluR1-expressing/GluR2-undetectable neurons possessed parvalbumin immunoreactivity. These results indicate that neurons in the rat somatosensory cortex express differential combinations of GluR subunits, which correlate with the specific expression of the calcium-binding proteins.

Key words: AMPA receptor; GluRs; calcium permeability; parvalbumin; calbindin-D28k; cortical neuron; nonradioactive in situ hybridization; immunocytochemistry
The AMPA-type glutamate receptors (AMPA receptor) are the principal mediators of fast excitatory neurotransmission in the mammalian CNS. They are composed of various combinations of four subunit proteins, GluR1, GluR2, GluR3, and GluR4 (or GluRA-D) (Seeburg, 1993; Hollmann and Heinemann, 1994; Westbrook, 1994). The mRNAs and proteins of these four receptor subunits were detected in the CNS using radioactive in situ hybridization (RI ISH) with radioisotope-labeled oligonucleotide probes (Sato et al., 1993; Tölle et al., 1993) and immunocytochemistry (ICC) with specific antibodies (Petralia and Wenthold, 1992; Martin et al., 1993), respectively. Although they are expressed ubiquitously, they show differential expression patterns in the rodent brains.

Expression studies using Xenopus oocytes or cultured human embryonic kidney (HEK) cells have shown that the presence of the GluR2 subunit determines both the rectification properties

Received Sept. 4, 1996; revised Dec. 6, 1996; accepted Dec. 13, 1996.

This work was supported by a Grant-in-Aid for scientific research from the Ministry of Education, Science, and Culture of Japan. We thank Professor K Takahashi (Meiji College of Pharmacy) for discussion and valuable advice on this experiment; Professor Y. Kidokoro (University of Gunma), Professor S. Ozawa (University of Gunma), and Dr. Y. Kubo (Tokyo Metropolitan Institute for Neuroscience; TMIN) for comments on this manuscript; Dr. T. Ichikawa (TMIN) for guidance on in situ hybridization and comments on this manuscript; Dr. S. Sasaki (TMIN) and Dr. T. Terashima (TMIN) for interesting discussions; and Dr. M. Hollmann and Dr. J. Boulter (The Salk Institute for Biological Studies, La Jolla, CA) for generously providing the GluR1 and GluR2 cDNA clones, respectively.

Correspondence should be addressed to Dr. Masahiro Kondo, Department of Neurobiology, Tokyo Metropolitan Institute for Neuroscience, 2-6 Musashidai, Fuchu, Tokyo 183, Japan.

Copyright (C) 1997 Society for Neuroscience $\quad 0270-6474 / 97 / 171570-12 \$ 05.00 / 0$ and the calcium permeability of the receptor channels (Hollmann et al., 1991; Hume et al., 1991; Geiger et al., 1995; Jonas and Burnashev, 1995). The AMPA receptor with GluR2 displays a linear or outward rectification and little calcium permeability. In contrast, the receptor lacking this subunit exhibits a strong inward rectification and a high calcium permeability. Furthermore, the desensitization kinetics of AMPA receptors are regulated by the expression of GluR4 splice variants (Mosbacher et al., 1994). Thus, differential expression of the GluR subunit genes could provide AMPA receptors in the CNS with functional diversity.

Native AMPA receptors in the majority of CNS neurons display little calcium permeability. However, AMPA receptors highly permeable to calcium were found in a small population of cultured rat hippocampal neurons (Iino et al., 1990; Gilbertson et al., 1991). Recent studies have shown that these receptors are expressed in a variety of CNS neurons and are involved in excitatory synaptic transmission. The single-cell reverse transcription (RT)PCR technique combined with patch-clamp recording has revealed that the relative abundance of the GluR2 subunit dominates the calcium permeability of native AMPA receptors (Lambolez et al., 1992; Bochet et al., 1994; Jonas et al., 1994; Jonas and Burnashev, 1995).

So far no attempt has been made to classify neurons in a certain area on the basis of differential combinations of GluR subunit expression. In this study, we classified individual neurons in the rat somatosensory cortex into four categories: type 1A [GluR1 $(+) /$ GluR2(+)], type 1B [GluR1(-)/GluR2(+)], type 2A [GluR1(+)/ 


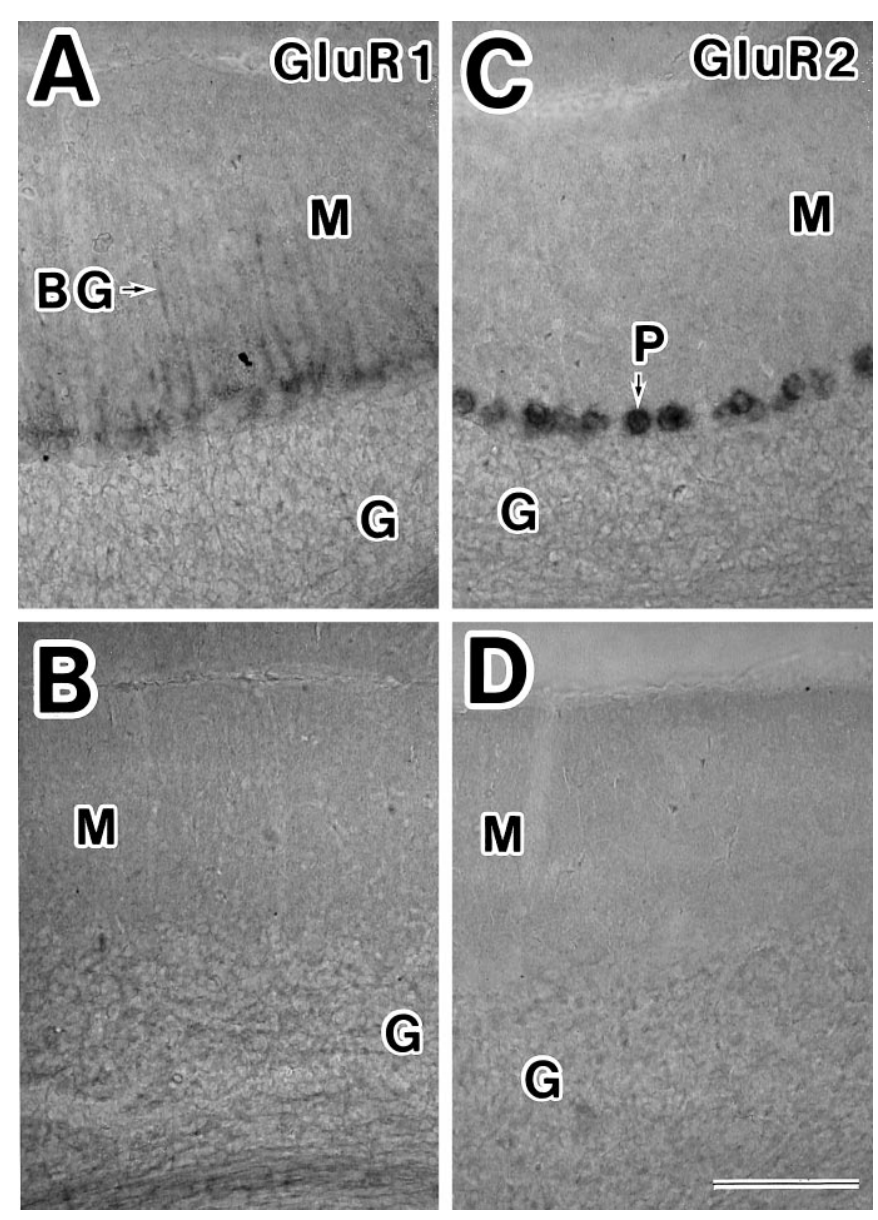

Figure 1. Distributions of GluR1 and GluR2 mRNAs in the cerebellum of adult rats. $A$, GluR1 mRNA was detected in the somata and processes (arrow) of Bergmann glial $(B G)$ cells. $C$, Intense staining of GluR2 mRNA was observed in the somata of Purkinje cells $(P)$. GluR2 mRNA was expressed very weakly in granule cells $(G) . B, D$, Adjacent sections of photomicrograph $A$ and $C$ were reacted with GluR1 $(B)$ and GluR2 $(D)$ sense strand probes. Labeled cells were not detected. $M$, Molecular layer; $G$, granule layer. Scale bar in $D, 100 \mu \mathrm{m}$.

GluR2(-)], and type 2B [GluR1(-)/GluR2(-)] with a doublelabeling technique using both non-RI ISH and ICC. AMPA receptors are expected to differ in their calcium permeability among these types of neurons. Very recently, an immunohistochemical study has shown that parvalbumin-positive neurons in the hippocampus of the rat and monkey express GluR1 and GluR4, but not GluR2/3, subunits, whereas calbindin-D28k-positive neurons are immunoreactive to GluR2/3 as well as to GluR1 and GluR4 (Leranth et al., 1996). Both parvalbumin and calbindin-D28k are calcium-binding proteins (CaBPs) that are thought to play a role in regulating intracellular calcium concentration (Baimbridge et al., 1992). Therefore, we further examined the specific expression of these CaBPs in the classified rat somatosensory neurons with a triple-labeling method using non-RI ISH and double-ICC.

\section{MATERIALS AND METHODS}

Tissue preparation. Sprague Dawley adult rats (250-300 gm) were anesthetized deeply with sodium pentobarbital (Nembutal, $40 \mathrm{mg} / \mathrm{kg}$, i.p.) and perfused first with cold PBS, pH 7.4, and subsequently with cold $4 \%$ paraformaldehyde (PFA) containing $0.2 \%$ saturated picric acid in PBS. Brains were removed, post-fixed overnight at $4^{\circ} \mathrm{C}$ in the same fixative solution, and then stored in $0.1 \mathrm{M}$ phosphate buffer (PB) containing $20 \%$ sucrose overnight at $4^{\circ} \mathrm{C}$. The frozen sections were cut in a coronal (for cerebral cortex) or sagittal (for cerebellum) plane at a thickness of $50 \mu \mathrm{m}$ by a microtome. The sections were rinsed in PBS and processed for ISH and ICC.

$R N A$ probe preparation. DNA templates for RNA synthesis were derived from the cloned rat cDNA sequences. The templates for GluR1 were a fragment of 275 base pairs (bp) corresponding to a part of the $3^{\prime}$ side coding region and the $3^{\prime}$ noncoding region (nucleotide residues 2467-2741 amplified using PCR; nucleotides were numbered starting with the first residue of the codon for the putative $\mathrm{N}$-terminal residue of the mature protein; Hollmann et al., 1989) and a fragment of $549 \mathrm{bp}$ corresponding to the $5^{\prime}$ side coding region (nucleotide residues 423-972 cut with PstI; Hollmann et al., 1989). The templates for GluR2 were a fragment of $360 \mathrm{bp}$ corresponding to the $3^{\prime}$ side coding region and the $3^{\prime}$ noncoding region (nucleotide residues 2479-2838 amplified using PCR; nucleotides were numbered starting with the first residue of the codon for the putative N-terminal residue of the mature protein; Boulter et al., 1990) and a fragment of 508 bp corresponding to the 5' side coding region (nucleotide residues 772-1279 cut with HincII; Boulter et al., 1990). These fragments were subcloned into the plasmid pBluescript II SK(-).

To produce antisense or sense strand probes, we linearized the plasmid with an appropriate restriction enzyme. RNA probes were synthesized by in vitro transcription according to the manufacturer's protocol using the T7 or T3 polymerase (Stratagene, La Jolla, CA) in the presence of digoxigenin-uridine $5^{\prime}$-triphosphate (DIG-UTP, Boehringer Mannheim, Indianapolis, IN). The labeling efficiency of GluR1 and GluR2 probes was tested by direct immunological detection on dot blots with a nucleic acid detection kit (Boehringer Mannheim).

In situ hybridization. The expression of GluR mRNAs was detected by the nonradioactive in situ hybridization technique. Free-floating brain sections were rinsed briefly twice in PBS and transferred into the following solutions: $0.4 \%$ Triton X-100 in PBS for $20 \mathrm{~min}$ at room temperature (RT); PBS for $5 \mathrm{~min} ; 0.2 \mathrm{~N} \mathrm{HCl}$ in distilled water for $20 \mathrm{~min}$ at RT; PBS for $5 \mathrm{~min}$; 4\% PFA in PB for $20 \mathrm{~min}$, and PBS for $5 \mathrm{~min}$. After these pretreatments, sections were placed into a prehybridization solution that consisted of $0.3 \mathrm{M} \mathrm{NaCl}, 50 \%$ formamide (FA), and $20 \mathrm{~mm}$ Tris- $\mathrm{HCl}, \mathrm{pH}$ 8.0 , for $1 \mathrm{hr}$ at RT and then incubated for $16 \mathrm{hr}$ at $50^{\circ} \mathrm{C}$ with the following hybridization solution: $0.5 \mathrm{mg} / \mathrm{ml}$ tRNA, $20 \mathrm{~mm}$ Tris- $\mathrm{HCl}, \mathrm{pH} 8.0,2.5 \mathrm{~mm}$ EDTA, $1 \times$ Denhardt's solution, $0.3 \mathrm{M} \mathrm{NaCl}, 50 \% \mathrm{FA}$, and $0.1 \%$ Tween 20 containing $0.1-0.3 \mu \mathrm{g} / \mathrm{ml}$ antisense or sense digoxigenin-labeled RNA probes. After hybridization, sections were washed with $2 \times$ SSC $(1 \times$ SSC: $0.15 \mathrm{M} \mathrm{NaCl}$ and $0.015 \mathrm{M}$ trisodium citrate) with $50 \%$ FA twice for $30 \mathrm{~min}$ each time at $50^{\circ} \mathrm{C}$. Then they were rinsed in $0.5 \mathrm{M} \mathrm{NaCl}$ in $10 \mathrm{~mm}$ Tris- $\mathrm{HCl}, \mathrm{pH} 8.0$, and treated with the same solution, including $20 \mu \mathrm{g} / \mathrm{ml}$ ribonuclease A (Boehringer Mannheim) and $10 \mathrm{U} / \mathrm{ml}$ ribonuclease $\mathrm{T}_{1}$ (Boehringer Mannheim). After a short rinse in $2 \times \mathrm{SSC}$ and $50 \% \mathrm{FA}$, these sections were washed in the same solution for $1 \mathrm{hr}$ at $50^{\circ} \mathrm{C}$ and washed in $1 \times \mathrm{SSC}$ with $50 \% \mathrm{FA}$ twice for $1 \mathrm{hr}$ each at $50^{\circ} \mathrm{C}$. Then they were placed in $100 \mathrm{~mm}$ Tris- $\mathrm{HCl}, \mathrm{pH} 7.5$, and $150 \mathrm{~mm} \mathrm{NaCl}$ (buffer 1) twice for $10 \mathrm{~min}$ each time and preincubated in the same buffer containing $1 \%$ blocking reagent (Boehringer Mannheim) (buffer 2). The sections were incubated overnight at $4^{\circ} \mathrm{C}$ in alkaline phosphatase (AP)-conjugated antibodies against digoxigenin (anti-digoxigenin-AP $\mathrm{Fab}$ fragment, Boehringer Mannheim) diluted 1:500 in buffer 2. For the removal of excess antibody, these sections were washed three times for 15 min each in buffer 1 and then equilibrated in a solution containing $100 \mathrm{~mm}$ Tris- $\mathrm{HCl}$, pH 9.5, $100 \mathrm{~mm} \mathrm{NaCl}$, and $50 \mathrm{mM} \mathrm{MgCl}_{2}$ (buffer 3) twice for 5 min each. The chromogenic reaction was executed in buffer 3 containing $4.5 \mathrm{mg} / \mathrm{ml}$ nitro blue tetrazolium salt and $3.5 \mathrm{mg} / \mathrm{ml} 5$-bromo-4-chloro-3indolyl phosphate (DIG nucleic acid detection kit, Boehringer Mannheim) until the signal was expressed, usually $\sim 5-8 \mathrm{hr}$. This reaction was stopped with $50 \mathrm{~mm}$ Tris- $\mathrm{HCl}, \mathrm{pH} 8.0$, and $100 \mathrm{~mm}$ EDTA.

Immunocytochemistry. After ISH, the sections were rinsed briefly in PBS, treated with $0.2 \%$ Triton X-100 in PBS for $30 \mathrm{~min}$ at RT, and then preincubated for blocking in PBS containing $2.5 \%$ normal goat serum (NGS) for $1 \mathrm{hr}$ at RT. They were incubated overnight at $4^{\circ} \mathrm{C}$ with two primary antibodies: one of anti-GluR1, $2 / 3$, and 4 antibodies $(2 \mu \mathrm{g} / \mathrm{ml}$, rabbit anti-glutamate receptor $1,2 / 3,4$ polyclonal antisera; Chemicon International, Temecula, CA) (Petralia and Wenthold, 1992; Wenthold et al., 1992), and one of anti-parvalbumin antibody (diluted 1:1000, monoclonal anti-parvalbumin mouse ascites fluid; Sigma, St. Louis, MO) (Celio et al., 1988) and anti-calbindin-D28k antibody (diluted 1:200, monoclonal anti-calbindin-D mouse ascites fluid; Sigma) (Celio et al., 1990). On the next day, the sections were washed three times for $5 \mathrm{~min}$ each time in PBS, treated in biotinylated anti-mouse IgG (diluted 1:200, second antibody for parvalbumin and calbindin-D28k; Vector Laboratories, Burlin- 

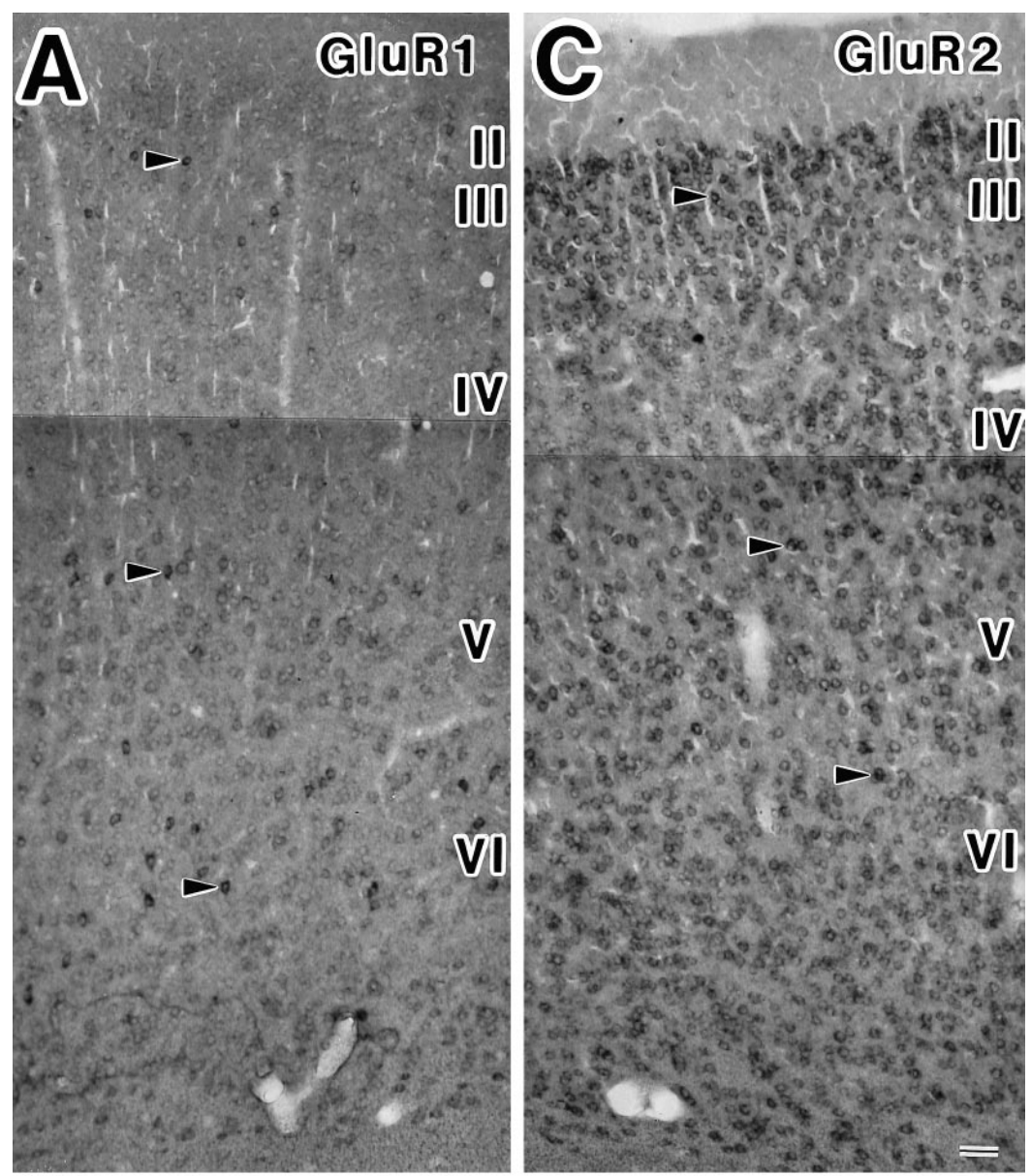

Figure 2. Zonal distribution and cellular localization of GluR1 and GluR2 mRNAs in the somatosensory cortex of adult rats. GluR1 $(A, B)$ and GluR2 $(C, D)$ mRNAs were observed in a unique expression pattern. $A, C$, Overview at low magnification. $A$, Many cortical neurons were weakly stained, and scattered neurons (arrowheads) were intensely stained with GluR1 antisense RNA probe throughout layers II-VI. $C$, Cortical neurons were moderately or strongly (arrowheads) stained with GluR2 antisense RNA probe throughout layers II-VI. B, High magnification of layer VI in A. Large arrows point to strong-labeled neurons, and small arrows point to weak-labeled neurons. $D$, High magnification of layer II/III in C. Arrows indicate GluR2-positive neurons. Asterisks indicate unlabeled cells in $B, D$. Scale bars in $B, D, 50 \mu \mathrm{m}$.
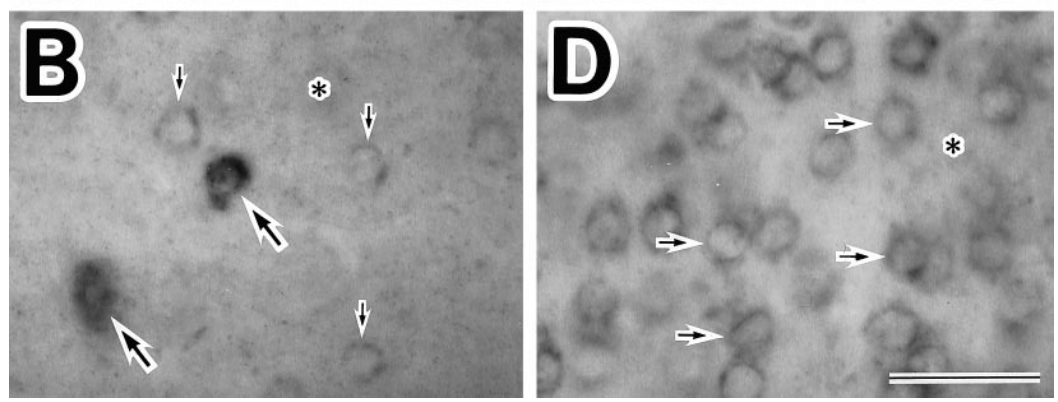

game, CA) for $1 \mathrm{hr}$ at RT, and washed three times for $10 \mathrm{~min}$ each again They were incubated in Cy3-conjugated AffiniPure goat anti-rabbit IgG (diluted 1:200, second antibody for detection of GluR1, 2/3, and 4; Jackson ImmunoResearch, West Grove, PA) and fluorescein (FITC)conjugated streptavidin (diluted 1:200, detection for parvalbumin and calbindin-D28k; Vector Laboratories) for $1 \mathrm{hr}$ at RT in a dark room. Then the sections were rinsed with PBS three times for 5 min each and were stained further with 4',6-diamidino-2-phenylindole dihydrochloride (DAPI, $0.5 \mu \mathrm{g} / \mathrm{ml}$; Nacalai Tesque) for several minutes. Sections were mounted on slides and coverslipped in PermaFluor (Lipshow/Immunon).

Quantitative analysis. To quantitate the proportions of the four types of classified neurons on the basis of the expression combinations of GluR1 and GluR2 subunits, we stained six sections of somatosensory cortex from three rats with DAPI after ISH and ICC. Regions (50-100) of $50 \times 50$ $\mu \mathrm{m}^{2}$ strips were selected randomly, and 200 neurons in the strips were classified. Neurons were identified by their characteristic nuclei: neuronal nuclei are identified by their size (generally greater than that of glial cells), by their nuclei with granular background, and by the relatively frequent presence of a well marked nucleolus; glial nuclei are identified by their small size (Leuba and Garey, 1989). Because it is still difficult, however, to distinguish neurons from glial cells clearly, obviously small nuclei intensely and homogeneously stained with DAPI were removed from the samples. Therefore, it is thought that all of the neurons and possibly some of the glial cells in a given strip were classified. The classified neurons also were studied for parvalbumin and calbindin-D28k immunoreactivity (see Fig. 4).

The number of parvalbumin and calbindin-D28k-immunoreactive neurons in each cortical layer was counted in six nonoverlapping $105 \times$ $160-\mu \mathrm{m}^{2}$-wide strips. The sections used were $50 \mu \mathrm{m}$ thick, and these counts were restricted to cells in focus. These positive neurons were classified into four types on the basis of expression combinations of GluR1 and GluR2 subunits (see Fig. 9).

\section{RESULTS}

\section{Confirmation of the specificity of GluR1 and GluR2 RNA probes}

Non-RI ISH was performed by digoxigenin-labeled RNA probes made from two templates containing different regions of GluR1 and GluR2 cDNAs, respectively.

As for cell populations in the cerebellum, the GluR1 transcript 

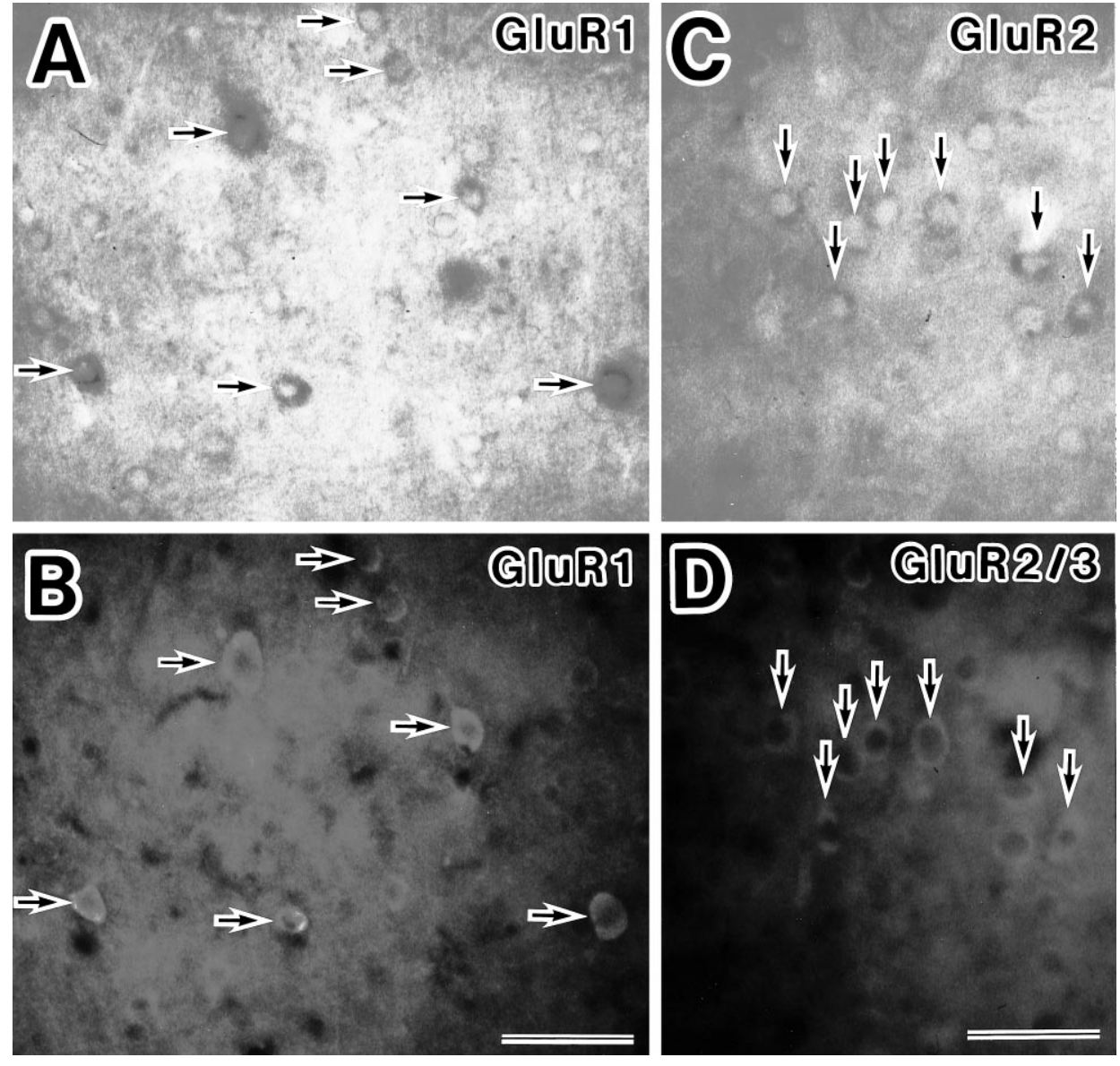

Figure 3. Double-staining experiments for GluR1 and GluR2 mRNA and the corresponding protein expression in neurons in the somatosensory cortex by in situ hybridization and immunocytochemistry. A, GluR1 mRNA-expressing neurons in layer VI were detected by a DIG-labeled GluR1 antisense probe and observed with bright-field illumination (arrows). B, GluR1 protein-expressing neurons were detected with anti-GluR1 antibody and observed under UV light epifluorescence in the same section of photomicrograph $A$. Those neurons labeled with the GluR1 antisense probe also showed the immunofluorescent signal for GluR1 antibody (arrows). The degree of the GluR1 mRNA expression was in proportion to that of GluR1 protein. $C, D$, Neurons labeled with the combination of the GluR2 antisense probe and GluR2/3 antibody. Most neurons in layer II/ III stained by the GluR 2 antisense probe also were labeled with GluR2/3 antibody (arrows). Scale bar, $50 \mu \mathrm{m}$. was observed in the somata and processes of Bergmann glial cells (Fig. 1A), whereas the GluR2 transcript was detected intensely within the somata of Purkinje cells (Fig. 1C) and was detected weakly in the granule cell layer (Fig. $1 C$ ). Other antisense probes derived from the different regions of GluR1 and GluR2 showed signals identical to those in Figure $1 A$ and $1 C$, respectively (data not shown). The GluR1 and GluR2 sense probes detected no signal (Fig. 1B,D).

The expression pattern in our study was generally similar to the results reported in previous studies (Sato et al., 1993; Catania et al., 1995) or ICC (Petralia and Wenthold, 1992; Jaarsma et al., 1995), but our method using nonradioactive RNA probe is estimated to be less sensitive than radioactive approaches, because GluR2 mRNA was detected weakly in granule cell layer in our present study, whereas it was detected strongly with radioactive oligonucleotide probes (Sato et al., 1993).

\section{GluR1 and GluR2 subunit transcripts in individual neurons of the somatosensory cortex}

Neurons containing GluR1 or GluR2 mRNAs were distributed widely in all cortical layers, but the number of neurons with GluR1 mRNA was smaller than that of neurons with GluR2 mRNA (Fig. 2).

The degree of the mRNA expression was analyzed in individual neurons. Neurons containing GluR1 subunits were divided into two types in terms of the degree of mRNA expressed: some scattered neurons were intensely labeled with the GluR1 antisense probe around their nuclei (arrowheads, Fig. $2 A$; large arrows, Fig. $2 B$ ), and most of the remaining GluR1-positive neurons were labeled weakly (Fig. $2 A$; small arrows, Fig. $2 B$ ). GluR2 mRNA expression was strong in some cells (arrowheads, Fig. 2C) but moderate in other cells (Fig. 2C; arrows, Fig. 2D). The neurons containing hardly visible or undetectable amounts of the GluR subunit were regarded as negative (asterisks, Fig. 2B,D).

\section{Classification of somatosensory neurons on the basis of combinations of AMPA receptor subunits}

Cortical neurons were classified into four categories: type 1A neurons [neurons containing both GluR1 and GluR2 subunits, GluR1(+)/GluR2(+)], type 1B neurons [neurons with GluR2 but undetectable GluR1 subunits, GluR1(-)/GluR2(+)], type 2A neurons [neurons containing GluR1 but undetectable GluR2 subunits, GluR1(+)/GluR2(-)], and type 2B neurons [neurons with undetectable GluR1 and GluR2 subunits, GluR1(-)/GluR2(-)].

To identify the neuronal types on the basis of expression combinations of AMPA receptor subunits in the somatosensory cortex, we performed the double-staining technique with GluR1 or GluR2 antisense RNA probes and anti-GluR1, anti-GluR2/3, or anti-GluR4 antibodies. The neurons labeled by the GluR1 antisense probe also showed immunoreactivity to anti-GluR1 antibody (Fig. 3A,B). This result indicated that the non-RI ISH reaction did not prevent immunoreaction for these antibodies.

Two hundred cells were selected at random from cortical layers II/III, IV, V, and VI, respectively (see Materials and Methods), and were classified using the double-labeling technique by the GluR2 antisense probe and anti-GluR1 antibody (Fig. 4). The percentages of type $1 \mathrm{~A}$ neurons in all cortical neurons of each layer were $10,8,15$, and $4.5 \%$ in layers II/III, IV, V, and VI, 


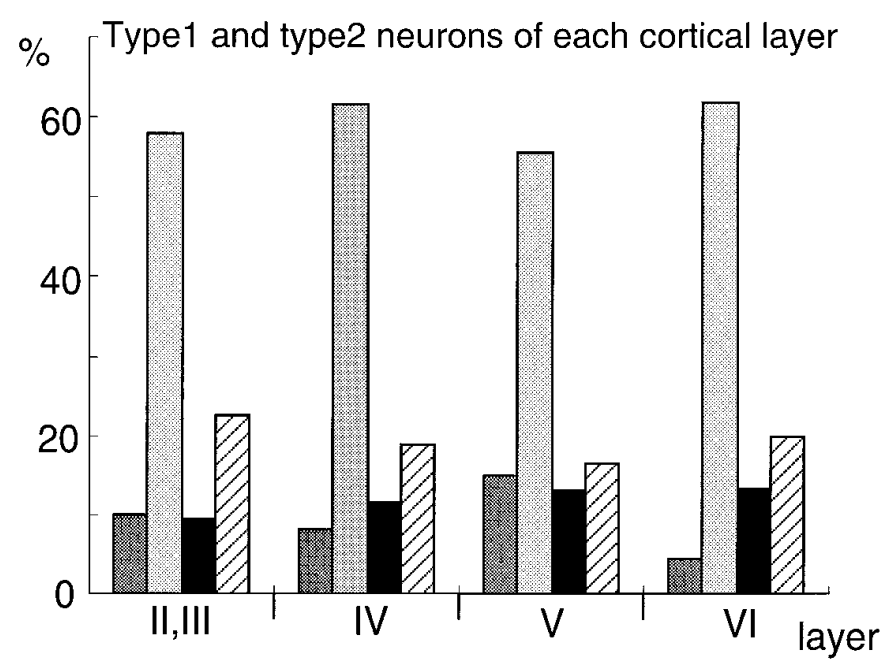

Figure 4. Histogram of each laminar distribution of the classified AMPAsensitive neurons in the rat somatosensory cortex. In each cortical layer (layers $I I / I I I, I V, V$, and $V I$ ), $50-100$ regions $50 \times 50 \mu \mathrm{m}^{2}$ were selected at random, and 200 neurons in each region were examined. The height of individual bars indicates the percentage of each type of neurons per total examined neurons in each layer. Dark gray bars, Type 1A neurons [GluR1(+)/GluR2(+)]; light gray bars, type 1B neurons [GluR1(-)/ GluR2(+)]; black bars, type 2A neurons [GluR1(+)/GluR2(-)]; slashed bars, type 2B neurons [GluR1(-)/GluR2(-)].

respectively, and more than one-half of the cortical neurons were type $1 \mathrm{~B}(58,61.5,55.5$, and $62 \%$, respectively). Type $2 \mathrm{~A}$ neurons were $9.5,11.5,13$, and $13.5 \%$ of cortical neurons in each layer, and type $2 \mathrm{~B}$ neurons were $22.5,19,16.5$, and $20 \%$.

The morphological study revealed that some type $1 \mathrm{~A}$ neurons were pyramidal cells (Fig. $5 A$ ), but some were nonpyramidal cells (Fig. $5 B$ ), and most type $2 \mathrm{~A}$ neurons were nonpyramidal cells (Fig. $5 C$ ). The above morphological analysis of type $1 \mathrm{~B}$ neurons was supported by the double-labeling method with GluR1 antisense probe and anti-GluR2/3 antibody, because the GluR2/3immunoreactive neurons had mainly GluR2 subunits, described below. The type 1B neurons in layers II/III, V, and VI were mainly pyramidal cells (Fig. 5D), whereas the neurons in layer IV contained both pyramidal and nonpyramidal cells (data not shown). Type 1A pyramidal neurons also were recognized (Fig. $5 D$ ).

Cortical neurons also were examined with the combination of GluR1 mRNA and GluR4 protein, GluR2 mRNA and GluR4 protein, and GluR 2 mRNA and GluR2/3 proteins. The majority of neurons immunoreactive to anti-GluR2/3 antibody were labeled with GluR2 antisense probe (Fig. 3C,D). The GluR4 subunit was observed in some nonpyramidal neurons and astrocytes (Fig. 6). Most neurons with the GluR4 subunit expressed GluR1, but not GluR2, subunits, indicating that neurons containing GluR4 subunits were type 2A (Fig. 6).

\section{The relation among the four types of neurons and CaBPs}

The relationship between the subunit combinations and the expression of CaBPs was investigated. As shown in Figure 7, most type 2A neurons expressed parvalbumin. GluR4-positive neurons lacking GluR2 subunits (subpopulation of type 2A, shown in Fig. 6) also showed parvalbumin immunoreactivity (Fig. 7). More than one-half of the pyramidal-shaped type 1B neurons in layer II/III lightly expressed calbindin-D28k protein, whereas the type $1 \mathrm{~A}$ neurons in layers II-VI were mainly bipolar or multipolar and showed intense calbindin-D28k immunoreactivity (Fig. 8).

Cortical neurons, which were selected randomly and classified in each layer, were analyzed for the presence of CaBPs (Table 1). We also counted the number of parvalbumin- or calbindin-D28k-positive neurons in six nonoverlapping $105 \times$ $160-\mu \mathrm{m}^{2}$-wide areas in each layer and classified these neurons by subunit combinations (Fig. 9). Parvalbumin-positive neurons were distributed equally in all cortical layers, with the exception of layer $\mathrm{I}$, and these neurons were almost all type $2 \mathrm{~A}$ neurons (Fig. 9A). The calbindin-D28k-immunoreactive neurons were almost all type $1 \mathrm{~A}$ neurons in layers II-VI and type 1B neurons in layer II/III (Fig. 9B).

\section{DISCUSSION}

\section{The classification of cortical neurons on the basis of GluR subunit expression}

The GluR2 subunits play a major role in the determination of the calcium permeability of the receptor channel (Jonas and Burnashev, 1995). GluR1-3 subunits are expressed abundantly in cortical neurons of layers II-VI, and the expression patterns of the GluR2 and GluR3 subunits are similar (Conti et al., 1994). In the present study, therefore, cortical neurons were classified with a double-staining method into four categories on the basis of their expression of GluR1 and GluR2 subunits (Figs. 4, 5). Because the sensitivity of our method using nonradioactive RNA probes is limited, the absolute number in cell population of each type

Table 1. Parvalbumin and calbindin-D28k expression in 100 neurons classified by GluR subunit combinations in each layer of somatosensory cortex

\begin{tabular}{|c|c|c|c|c|c|c|}
\hline & Layer & $\begin{array}{l}\text { Type 1A } \\
\text { GluR1 }(+), 2(+)\end{array}$ & $\begin{array}{l}\text { Type 1B } \\
\text { GluR1(-), 2(+) }\end{array}$ & $\begin{array}{l}\text { Type 2A } \\
\text { GluR1 }(+), 2(-)\end{array}$ & $\begin{array}{l}\text { Type 2B } \\
\text { GluR1 }(-), 2(-)\end{array}$ & Total \\
\hline & II, III & $2(10)$ & $0(53)$ & 7 (11) & $0(26)$ & $9(100)$ \\
\hline PV & IV & $1(8)$ & $0(57)$ & 7 (11) & $0(24)$ & $8(100)$ \\
\hline \multirow[t]{3}{*}{$(+)$} & $\mathrm{V}$ & $0(15)$ & $0(46)$ & $12(15)$ & $0(24)$ & $12(100)$ \\
\hline & VI & $0(3)$ & $0(54)$ & $12(14)$ & $0(29)$ & $12(100)$ \\
\hline & II, III & $8(10)$ & $29(63)$ & $0(8)$ & $3(19)$ & $40(100)$ \\
\hline $\mathrm{CB}$ & IV & $3(8)$ & $0(66)$ & $2(12)$ & $1(14)$ & $6(100)$ \\
\hline \multirow[t]{2}{*}{$(+)$} & V & $9(15)$ & $0(65)$ & $3(11)$ & $0(9)$ & $12(100)$ \\
\hline & VI & $5(6)$ & $0(70)$ & $2(13)$ & $0(11)$ & $7(100)$ \\
\hline
\end{tabular}

Total number of each type of neuron collected for sections is given in parentheses. 

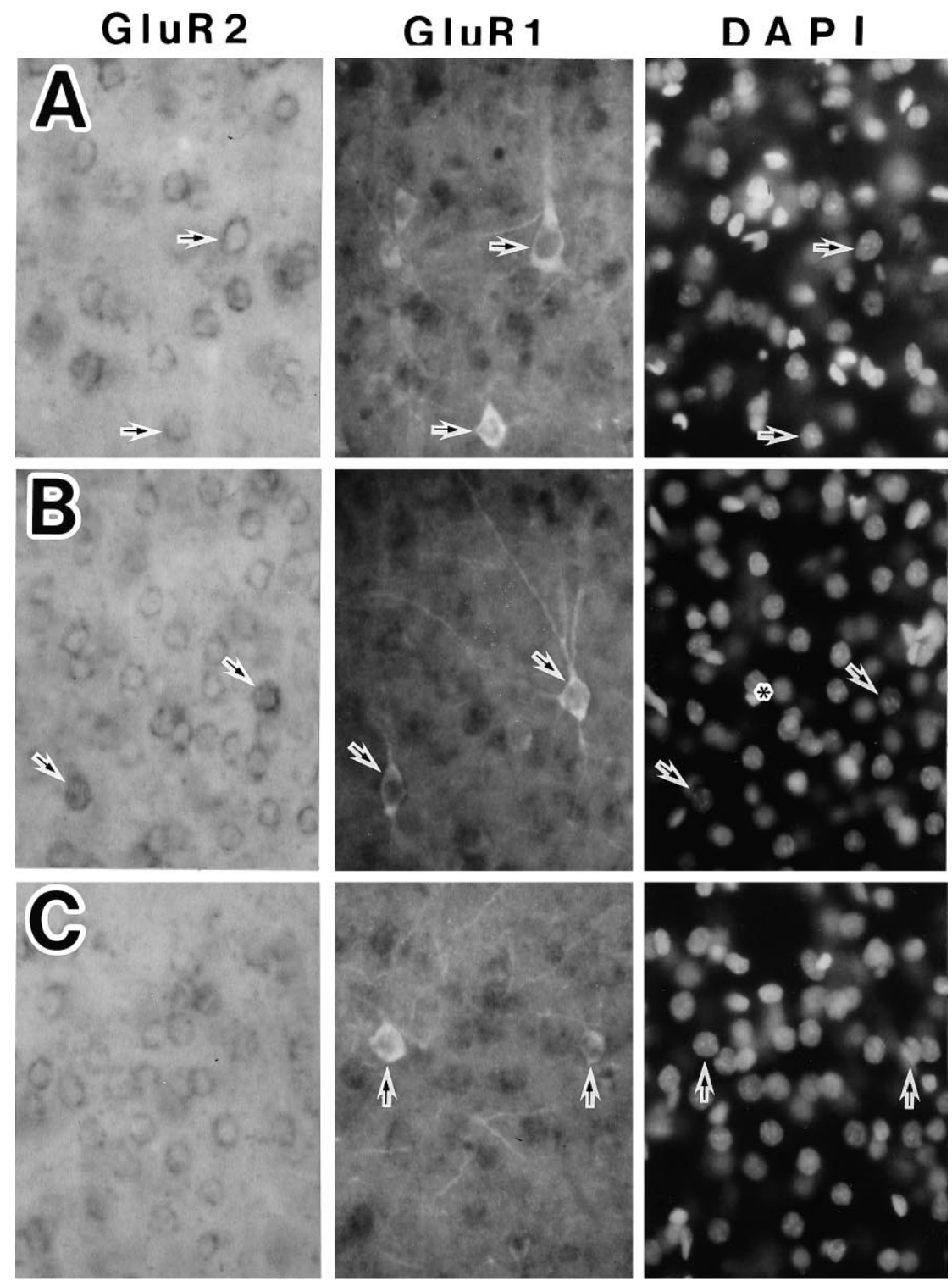

\section{GIuR 1}

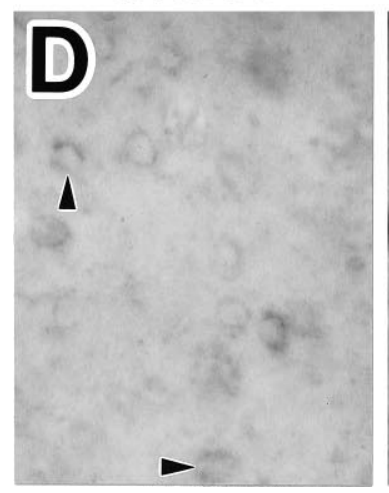

\section{GluR2/3}

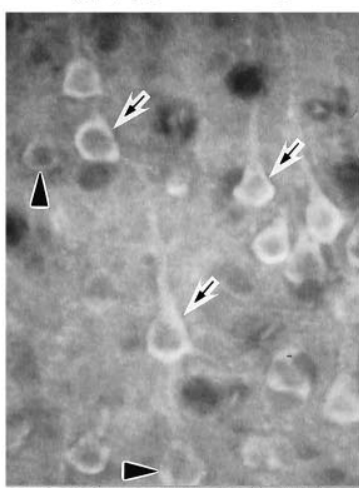

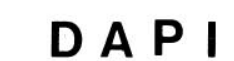

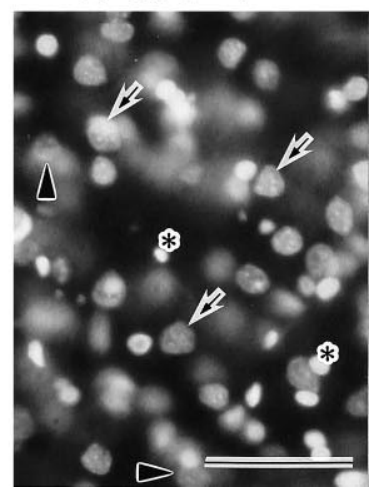

Figure 5. Morphological classification of three types of AMPA-sensitive neurons in the somatosensory cortex. Shown are in situ hybridization with the GluR1 or GluR2 antisense RNA probe (left panels), immunocytochemistry with polyclonal GluR1 or GluR2/3 antibody (center panels), and DAPI staining (right panels) in the same section. $A-C$, A combination of staining with the GluR2 antisense probe and anti-GluR1 antibody. $A$, Type 1A neurons with pyramidal shapes in layer $\mathrm{V}$ (arrows). B, Type 1A neurons with nonpyramidal shapes in layers V and VI (arrows). C, Type 2A neurons with nonpyramidal shapes in layer VI (arrows). $D$, A combination of staining with the GluR1-antisense probe and anti-GluR2/3 antibody. Type 1B neurons with pyramidal shapes appear in layer V (arrows). Type 1A pyramidal neurons are observed the same as in $A$ (arrowheads). Also shown are DAPI-stained glial cells with small nuclei (asterisks). Scale bar, $50 \mu \mathrm{m}$. should not be regarded as showing the strict quantitative estimation but, rather, the general tendency.

Although the GluR1 and GluR2 subunits were found to be expressed abundantly in cortical neurons, type $1 \mathrm{~A}$ neurons were unexpectedly few $(\sim 10 \%)$. The GluR1 and GluR2 subunits thus seemed to be regulated differentially.

Type 1B neurons were found in abundance $(\sim 60 \%)$, and they were pyramidal cells in layers II/III, V, and VI. In layer IV, 

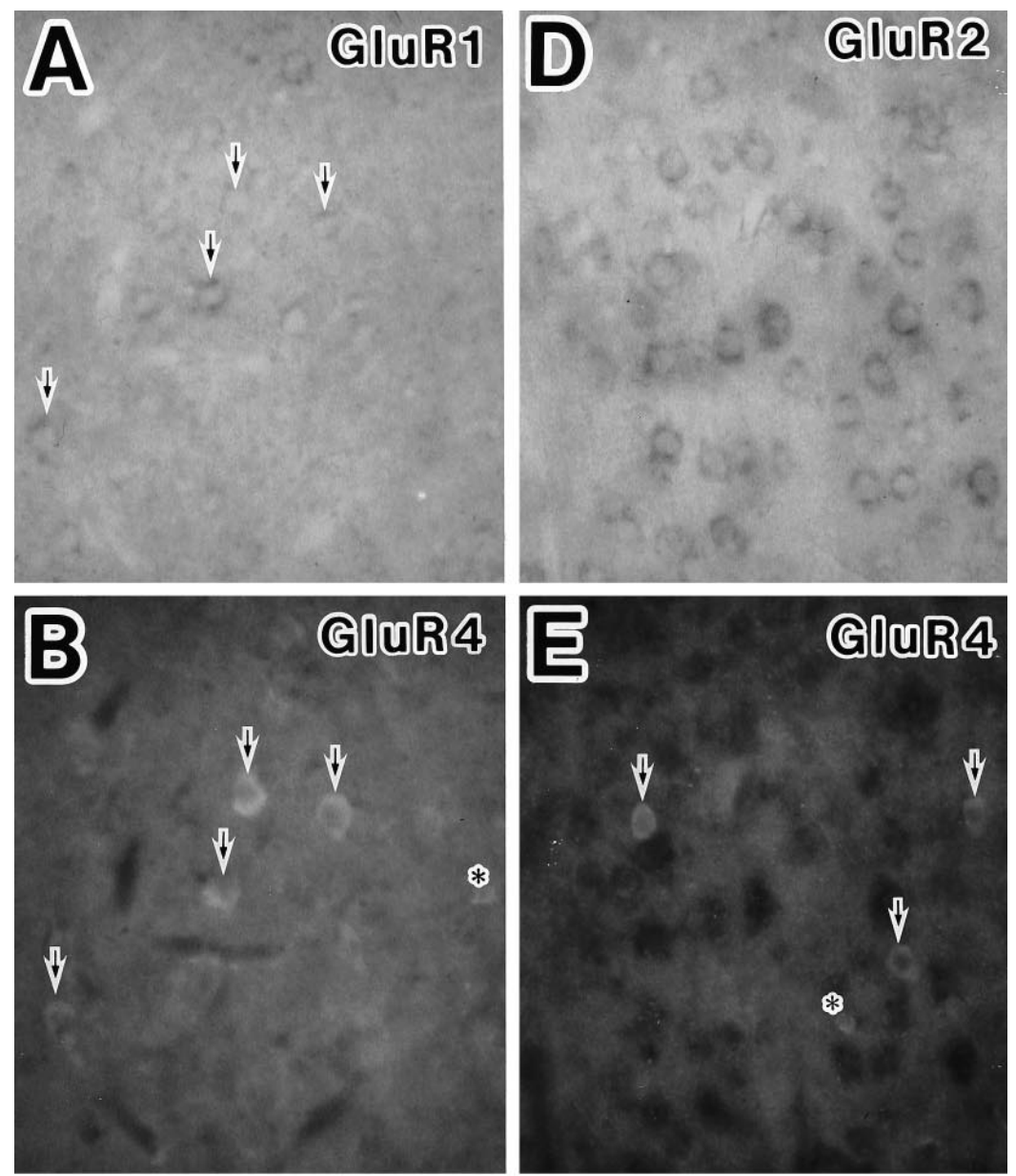

Figure 6. Double-staining experiments for expression of GluR1 mRNA, GluR2 mRNA, and GluR4 protein in layer V of the somatosensory cortex. $A-C$, GluR4-positive neurons $(B)$ express GluR1 mRNA $(A)$ (arrows). Nuclei are stained with DAPI $(C) . D-F$, GluR4-immunoreactive neurons $(E)$ do not exhibit GluR2 mRNA $(D)$ (arrows). Nuclei are stained with DAPI $(F)$. Some astrocytes are stained with anti-GluR4 antibody (asterisks in $B, C, E, F$ ). Scale bar, $50 \mu \mathrm{m}$.
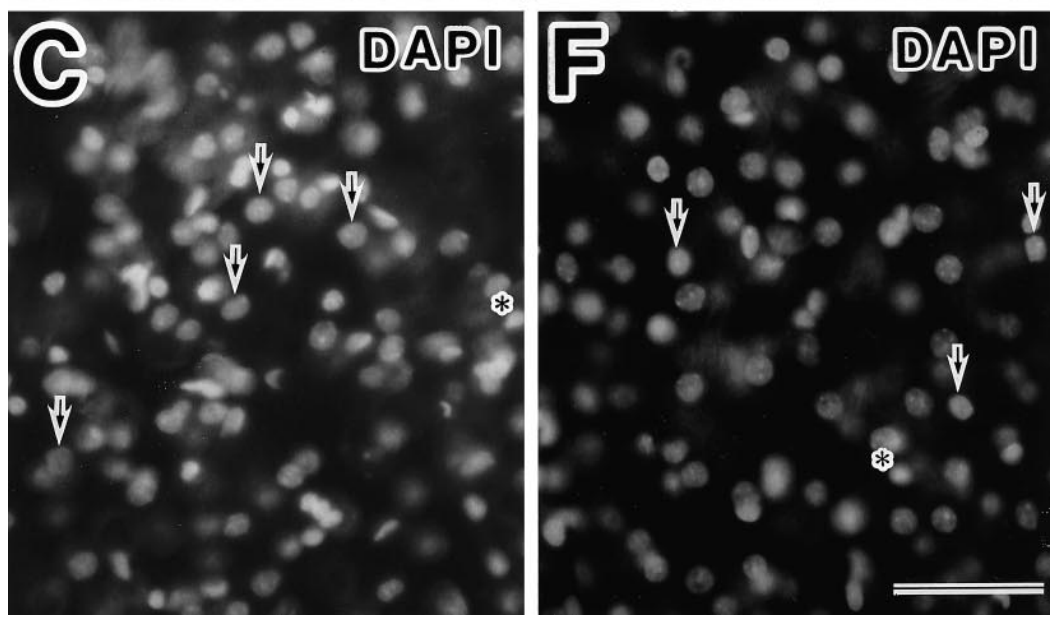

they were not only pyramidal cells but also nonpyramidal cells. A type of nonpyramidal cells termed spiny stellate cells, which are confined to layer IV of the primary sensory cortex, have some pyramidal attributes, i.e., spiny dendrites and asymmetric synapse; they are considered modified pyramidal neurons (Nieuwenhuys, 1994). Therefore, it is speculated that the type 1B nonpyramidal neurons in layer IV correspond to these modified pyramidal cells. If this speculation is correct, type $1 \mathrm{~B}$ neurons are, in general, pyramidal cells. Most pyramidal cells were type $1 \mathrm{~B}$, and the remaining pyramidal cells were type $1 \mathrm{~A}$. Therefore, cortical pyramidal cells have AMPA receptors impermeable to calcium.
Type 2A neurons constituted $10-15 \%$ of cortical neurons and had mostly nonpyramidal shapes. In a hippocampal culture study, a few nonpyramidal neurons, named type II, exhibited a strong inward rectification and a high calcium permeability (Iino et al., 1990), and the single-cell RT-PCR and patch-clamp studies revealed that they express only two subunits, GluR1 and GluR4 (Bochet et al., 1994). Our classified type 2A neurons correspond to type II neurons. In the somatosensory cortex, some of the type 2A neurons lacked the GluR4 subunit.

In visual cortex brain slices, a single-cell RT-PCR and patchclamp study found that GluR2 mRNA was undetectable in 1 of 12 fast-spiking nonpyramidal cells and that the relative abun- 

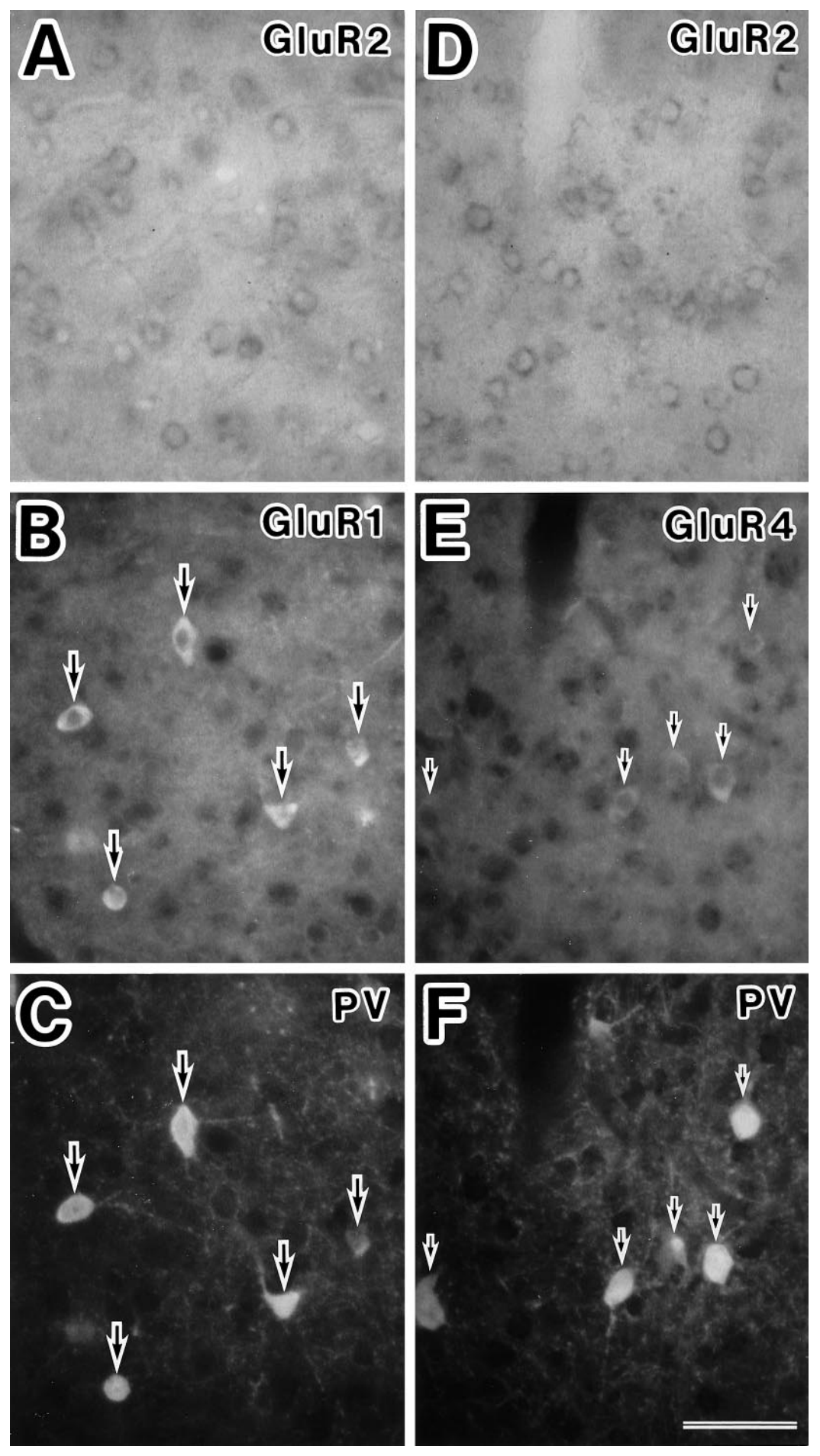

Figure 7. Detection of parvalbumin in classified neurons using the triple-staining technique. $A-C$, In situ hybridization with the GluR2 antisense probe $(A)$, immunocytochemistry with polyclonal GluR1 antibody $(B)$, and monoclonal parvalbumin antibody $(C)$ in the same section of cortical layer VI. Representative neurons with GluR1 subunit, but not GluR2 subunit (type 2A), exhibit parvalbumin immunoreactivity (large arrows). D-F, In situ hybridization with the GluR2 antisense probe $(D)$, immunocytochemistry with GluR4 antibody $(E)$, and parvalbumin antibody $(F)$ in the same section of cortical layer VI. Representative neurons with GluR4 subunits, but not GluR2 subunits (putative type 2A), exhibit parvalbumin immunoreactivity (small arrows). PV, Parvalbumin. Scale bar, $50 \mu \mathrm{m}$. dance of GluR2 mRNA was significantly lower in nonpyramidal than in pyramidal cells (Jonas et al., 1994). These results differ from our results in the proportion of type $2 \mathrm{~A}$ neurons detected. There are two possible explanations for this discrepancy: (1) The nonpyramidal neurons examined in the Jonas study belong to type $1 \mathrm{~A}$ rather than to type $2 \mathrm{~A}$, and (2) The detection sensitivity is comparatively lower in our double-staining method than in their single-cell RT-PCR technique. In fact, GluR1 mRNA was not detected in Purkinje cells and GluR2 mRNA was detected only weakly in granule cells by our in situ hybridization, whereas these were detected by the single-cell
RT-PCR technique (Jonas et al., 1994). In addition, it is estimated that our non-RI ISH method with RNA probes was not as highly sensitive as RI ISH approaches. Nevertheless, our double-staining method is useful in the analysis of the biological properties of cortical neurons, because we found a correlation between the combination of GluR subunits and the expression of CaBP using this method. The double-staining with the GluR1 RNA antisense probe and anti-GluR1 antibody indicated that the detection sensitivities of non-RI ISH and ICC were comparable (Fig. 3A,B).

GluR4-positive neurons mostly expressed GluR1 subunits (Fig. 

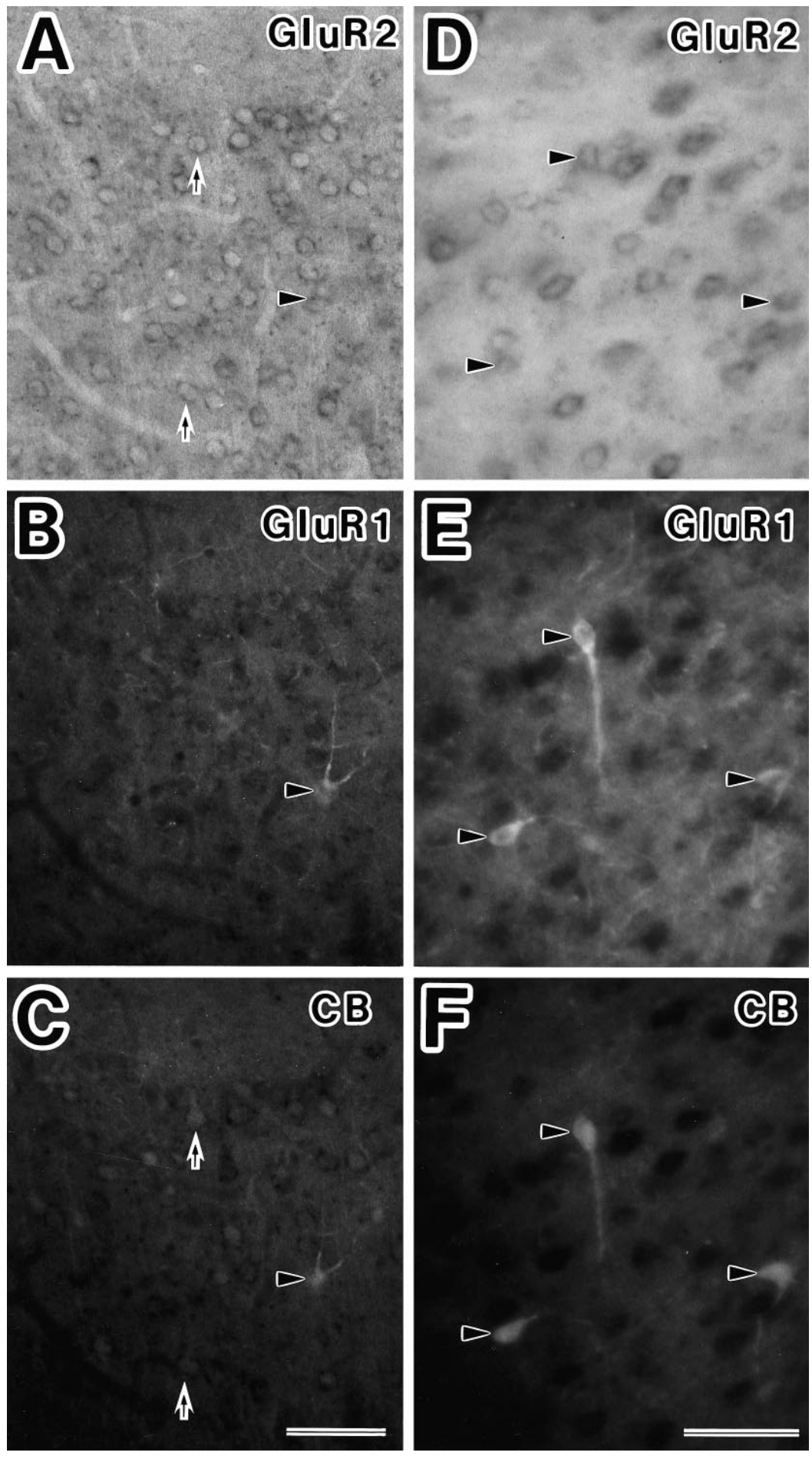

Figure 8. Detection of calbindin-D28k in classified neurons using the triple-staining technique. $A-C$, The type $1 \mathrm{~A}$ (arrowheads) and type 1B (arrows) neurons in layer II/III had calbindin-D28k immunoreactivity. $D-F$, The nonpyramidal type 1A neurons in layer VI (arrowhead) were stained with calbindin-D28k antibody. $C B$, CalbindinD28k. Scale bar, $50 \mu \mathrm{m}$.

$6 A-C)$, and most GluR2/3-immunoreactive neurons expressed GluR2 mRNA (Fig. 3C,D). Therefore, the type 2B neurons are presumed to have no GluR1-4 subunits or those in a fairly low level. It is estimated that the present double-staining method is less sensitive than RI ISH approaches and the single-cell RT-PCR technique, as discussed above. Therefore, there is a possibility that type $2 \mathrm{~B}$ neurons express GluR1 and/or GluR2 subunits in a low level. Type $2 \mathrm{~B}$ neurons were $\sim 1 / 5$ of the cortical neurons. When the neurons were classified, they were identified by neuronal characteristic nuclei. Because it is difficult to distinguish neurons from glial cells clearly, the type $2 \mathrm{~B}$ neuron count may contain some glial cells.

\section{The relation between the four types of cortical neurons and the expression of CaBPs}

The intracellular free calcium concentration is regulated by the capacity of the receptor-specific calcium permeability and calcium-binding affinity of CaBPs. Parvalbumin and calbindinD28k belong to the high-affinity CaBPs of the EF-hand family 

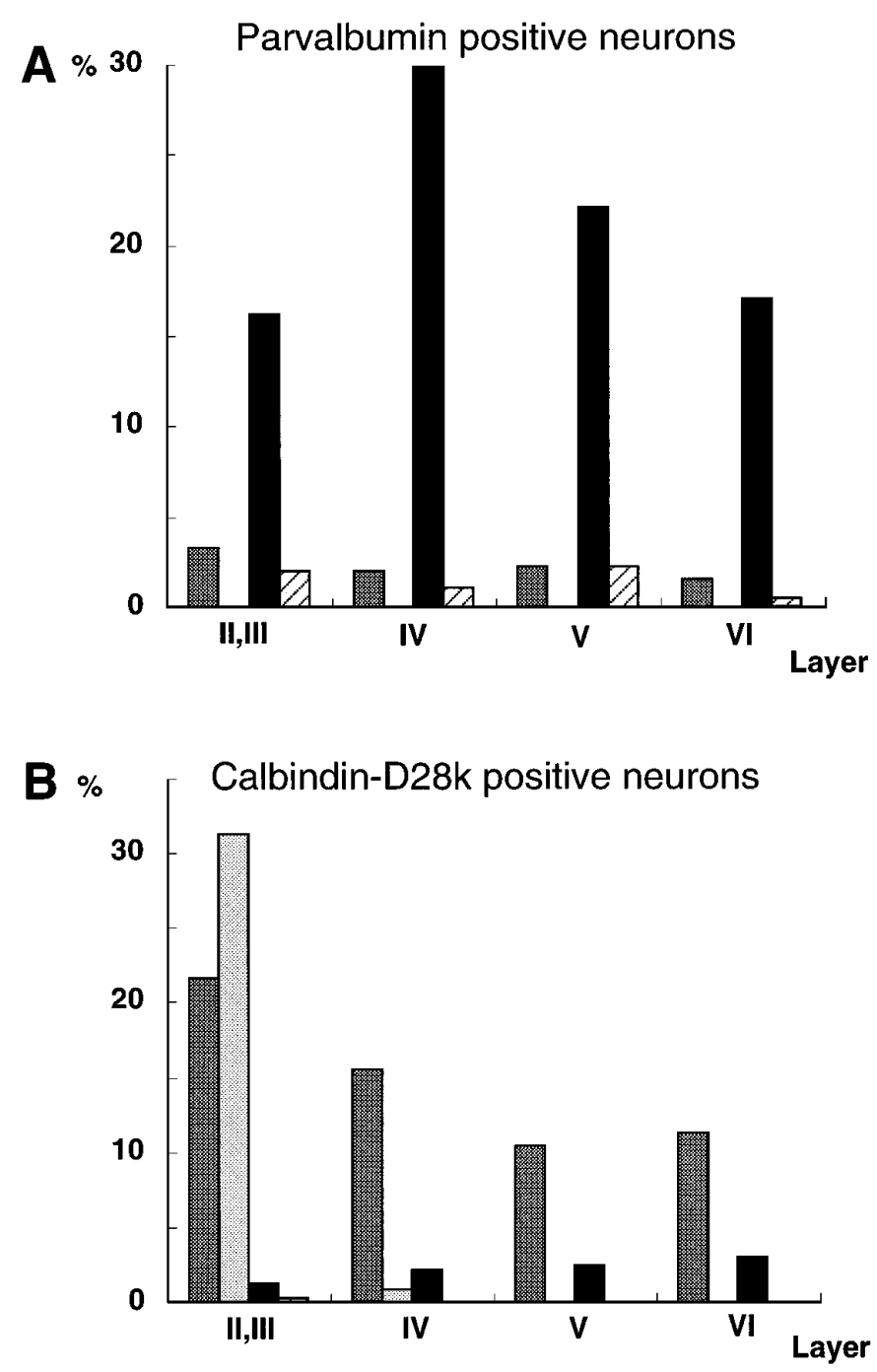

Figure 9. Histograms of the number of CaBP-positive (parvalbumin, $A$; calbindin-D28k, $B$ ) neurons in the classified four types of neurons in each cortical layer (layers $I I / I I I, I V, V$, and $V I$ ). The number of CaBP-positive neurons was counted in six $105 \times 160 \mu \mathrm{m}^{2}$ regions in three adult rats and summarized. The numbers of positive neurons are expressed as the percentage of the total number of counted parvalbumin- or calbindin-D28kpositive cells in all layers. $A$, The majority of parvalbumin-positive neurons was type $2 \mathrm{~A}$ neurons. $B$, Calbindin-D28k immunoreactivity was observed mainly in type $1 \mathrm{~A}$ neurons of the neocortical layer, with the exception of layer $I$, whereas type $1 \mathrm{~B}$ neurons with calbindin-D28k signal were restricted to layer II/III. Dark gray bars, Type 1A neurons [GluR1(+)/ GluR2(+)]; light gray bars, type 1B neurons [GluR1(-)/GluR2(+)]; black bars, type 2A neurons [GluR1(+)/GluR2(-)]; slashed bars, type 2B neurons [GluR1(-)/GluR2(-)].

(Persechini et al., 1989; Baimbridge et al., 1992). Because they are believed to act as buffer proteins in vivo (Baimbridge et al., 1992), the neuronal type of these proteins used in the present experiment is considered to be related to calcium permeability.

Most type 2A neurons had parvalbumin immunoreactivity (Table 1), and, conversely, most parvalbumin-immunoreactive cells were type $2 \mathrm{~A}$ neurons. This result is consistent with the report that $14 \%$ of all neurons were parvalbumin-immunoreactive in the rat somatosensory cerebral cortex (Ren et al., 1992). Because parvalbumin is found virtually only in GABA neurons in the cerebral cortex (Celio, 1986, 1990; van Brederode et al., 1991; Ren et al.,
1992), type 2A neurons must be GABAergic. This is consistent with the finding via the single-cell PCR technique that the type II neurons corresponding to type $2 \mathrm{~A}$ neurons in cultured hippocampal neurons contained glutamic acid decarboxylase (GAD) mRNA (Bochet et al., 1994).

Our present results indicate a specific correlation in individual neurons between the expression of a certain type of CaBPs and a specific combination of GluR subunits. This is consistent with the recent report in the hippocampus (Leranth et al., 1996).

\section{Expression of CaBPs and vulnerability to excitatory amino acid-inducing neurotoxicity}

Systems for calcium homeostasis are likely to be involved in neurodegenerative conditions. Of particular relevance to the calcium homeostasis is the relation of excitatory amino acid neurotoxicity and CaBPs buffering affinity to the phenomenon of selective neuronal vulnerability. It was reported that parvalbuminimmunoreactive striatal neurons in vivo and cultured cortical neurons were susceptible to application of excitatory amino acids (Weiss et al., 1990; Waldvogel et al., 1991; Heizmann and Braun, 1992), whereas cultured hippocampal neurons containing calbindin-D28k were protected from degeneration by excitatory amino acids (Mattson et al., 1991; Heizmann and Braun, 1992). Parvalbumin binds calcium with a dissociation constant of $\sim 10^{-7}$ $\mathrm{M}$ and the dissociation constant for magnesium is $\sim 10^{-4} \mathrm{M}$, whereas calbindin-D28k seems to have four high-affinity calciumbinding sites $\left(K_{\mathrm{D}}=2 \times 10^{-6} \mathrm{M}\right)$ and 20-30 low-affinity sites $\left(K_{\mathrm{D}}=10^{-3} \mathrm{M}\right)$ (Van Eldik et al., 1982). Because there seems to be little difference in their calcium-binding affinities, it is difficult to explain their differential neuronal vulnerability only on the basis of their differential expression of CaBPs. In our present study, we found that parvalbumin-positive neurons were almost all type $2 \mathrm{~A}$ neurons, which exhibited high calcium permeability, and calbindin-D28k-positive neurons were almost all type $1 \mathrm{~A}$ or type $1 \mathrm{~B}$ neurons, which exhibited low calcium permeability. We propose that the neurotoxicities may be regulated mainly by the combination of GluR subunits rather than by the differential expression of CaBPs. It has been shown that the majority of nitric oxide synthase (NOS)-positive neurons expressed GluR1 mRNA, but not GluR2 mRNA (Catania et al., 1995), and were not parvalbumin-immunoreactive (Dun et al., 1994). NOS-positive neurons are presumed to belong to a parvalbumin-negative subpopulation of type $2 \mathrm{~A}$ neurons, as shown in Table 1 . They have been shown both in vitro as well as in vivo to be susceptible to AMPA-induced excitotoxicity (Beal et al., 1991; Weiss et al., 1994), which supports our proposal.

In fact, initially, the neurotoxicity was thought to be caused by calcium influx through NMDA receptor channels (MacDermott et al., 1986; Choi, 1988). It was demonstrated, however, that the AMPA receptor also was involved in the neurotoxicity (Buchan et al., 1991).

In a model of hippocampal epilepsy, the basket cells containing calcium-permeable AMPA receptors were shown to be resistant, whereas mossy cells containing impermeable receptors were vulnerable (Sloviter, 1987, 1989; Geiger et al., 1995). These findings do not support our proposal. Recently, it was reported that selectively resistant motoneurons in amyotrophic lateral sclerosis (ALS) contain an abundance of parvalbumin, whereas a scarcity of parvalbumin is found in ALS-sensitive motor pools (Elliott and Snider, 1995; Reiner et al., 1995), which suggested that parvalbumin has the ability to protect neurons. The 
basket cells express parvalbumin, whereas the mossy cells do not (Ribak et al., 1990). Therefore, the resistance of the basket cells may be explained by their containing parvalbumin enough to buffer excess calcium through calcium-permeable AMPA receptors, whereas the vulnerability of mossy cells may be explained by their lacking parvalbumin to buffer excess calcium caused by epileptic stimuli. Geiger et al. (1995) found that the calciumimpermeable AMPA receptors in the mossy cells show the slowest desensitization and speculated that tonic release of glutamate by epileptic stimuli could cause depolarization and extensive calcium entry through NMDA receptors and voltage-dependent $\mathrm{Ca}^{2+}$ channels. The neurotoxicity might be determined by a balance between calcium entry induced by AMPA receptors and the degree of CaBPs.

\section{REFERENCES}

Baimbridge KG, Celio MR, Rogers JH (1992) Calcium-binding proteins in the nervous system. Trends Neurosci 15:303-308.

Beal MF, Ferrante RJ, Swartz KJ, Kowall NW (1991) Chronic quinolinic acid lesions in rat closely resemble Huntington's disease. J Neurosci 11:1649-1659.

Bochet P, Audinat E, Lambolez B, Crépel F, Rossier J, Iino M, Tuzuki K, Ozawa S (1994) Subunit composition at the single-cell level explains functional properties of a glutamate-gated channel. Neuron 12:383-388.

Boulter J, Hollmann M, O'Shea-Greenfield A, Hartley M, Deneris E, Maron C, Heinemann S (1990) Molecular cloning and functional expression of glutamate receptor subunit genes. Science 249:1033-1037.

Buchan AM, Li H, Cho S, Puslinelli WA (1991) Blockade of the AMPA receptor prevents CA1 hippocampal injury following severe but transient forebrain ischemia in adult rats. Neurosci Lett 132:255-258.

Catania MV, Tölle TR, Monyer H (1995) Differential expression of AMPA receptor subunit in NOS-positive neurons of cortex, striatum, and hippocampus. J Neurosci 15:7046-7061.

Celio MR (1986) Parvalbumin in most $\gamma$-aminobutyric acid-containing neurons of the rat cerebral cortex. Science 231:995-997.

Celio MR (1990) Calbindin D-28k and parvalbumin in the rat nervous system. Neuroscience 35:375-475.

Celio MR, Baier W, Schärer L, Viragh PA, de Gerday C (1988) Monoclonal antibodies directed against the calcium-binding protein parvalbumin. Cell Calcium 9:81-86.

Celio MR, Baier W, Schärer L, Gregersen HJ, Viragh PA, de Norman AW (1990) Monoclonal antibodies directed against the calciumbinding protein calbindin D-28k. Cell Calcium 11:599-602.

Choi DW (1988) Calcium-mediated neurotoxicity: relationship to specific channel types and role in ischemic damage. Trends Neurosci 11:465-469.

Conti F, Minelli A, Brecha NC (1994) Cellular localization and laminar distribution of AMPA glutamate receptor subunits mRNAs and proteins in the rat cerebral cortex. J Comp Neurol 350:241-259.

Dun NJ, Huang R, Dun SL, Förstermann U (1994) Infrequent colocalization of nitric oxide synthase and calcium-binding proteins immunoreactivity in rat neocortical neurons. Brain Res 666:289-294.

Elliott JL, Snider WD (1995) Parvalbumin is marker of ALS-resistant motor neurons. NeuroReport 6:449-452.

Geiger JRP, Melcher T, Koh D-S, Sakmann B, Seeburg PH, Jonas P, Monyer H (1995) Relative abundance of subunit mRNAs determines gating and $\mathrm{Ca}^{2+}$ permeability of AMPA receptors in principal neurons and interneurons in rat CNS. Neuron 15:193-204.

Gilbertson TA, Scobey R, Wilson M (1991) Permeation of calcium ions through non-NMDA glutamate channels in retinal bipolar cells. Science 251:1613-1615.

Heizmann CW, Braun K (1992) Changes in $\mathrm{Ca}^{2+}$-binding proteins in human neurodegenerative disorders. Trends Neurosci 15:259-264.

Hollmann M, Heinemann S (1994) Cloned glutamate receptors. Annu Rev Neurosci 17:31-108.

Hollmann M, O’Shea-Greenfield A, Rogers SW, Heinemann S (1989) Cloning by functional expression of a member of the glutamate receptor family. Nature 342:643-648.

Hollmann M, Hartley M, Heinemann S (1991) $\mathrm{Ca}^{2+}$ permeability of
KA-AMPA-gated glutamate receptor channels depends on subunit composition. Science 252:851-853.

Hume RI, Dingledine R, Heinemann SF (1991) Identification of a site in glutamate receptor subunits that controls calcium permeability. Science 253:1028-1031.

Iino M, Ozawa S, Tuzuki K (1990) Permeation of calcium through excitatory amino acid receptor channels in cultured rat hippocampal neurones. J Physiol (Lond) 424:151-165.

Jaarsma D, Wenthold RJ, Mugnaini E (1995) Glutamate receptor subunits at mossy fiber-unipolar brush cell synapses: light and electron microscopic immunocytochemical study in cerebellar cortex of rat and cat. J Comp Neurol 357:145-160.

Jonas P, Burnashev N (1995) Molecular mechanisms controlling calcium entry through AMPA-type glutamate receptor channels. Neuron 15:987-990.

Jonas P, Racca C, Sakmann B, Seeburg PH, Monyer H (1994) Differences in $\mathrm{Ca}^{2+}$ permeability of AMPA-type glutamate receptor channels in neocortical neurons caused by differential GluR-B subunit expression. Neuron 12:1281-1289.

Lambolez B, Audinat E, Bochet P, Crépel F, Rossier J (1992) AMPA receptor subunits expressed by single Purkinje cells. Neuron 9:247-258.

Leranth C, Szeidemann Z, Hsu M, Buzsáki G (1996) AMPA receptors in the rat and primate hippocampus: a possible absence of GluR2/3 subunits in most interneurons. Neuroscience 70:631-652.

Leuba G, Garey LJ (1989) Comparison of neuronal and glial numerical density in primary and secondary visual cortex of man. Exp Brain Res 77:31-38.

MacDermott AB, Mayer ML, Westbrook GL, Smith SJ, Barker JL (1986) NMDA-receptor activation increases cytoplasmic calcium concentration in cultured spinal cord neurons. Nature 321:519-522.

Martin LJ, Blackstone CD, Levey AI, Huganir RL, Price DL (1993) AMPA glutamate receptor subunits are differentially distributed in rat brain. Neuroscience 53:327-358.

Mattson MP, Rychlik B, Chu C, Christakos S (1991) Evidence for calcium-reducing and excito-protective roles for the calcium-binding protein calbindin-D28k in cultured hippocampal neurons. Neuron 6:41-51.

Mosbacher J, Schoepfer R, Monyer H, Burnashev N, Seeburg PH, Ruppersberg JP (1994) A molecular determinant for submillisecond desensitization in glutamate receptors. Science 266:1059-1062.

Nieuwenhuys R (1994) The neocortex. Anat Embryol (Berl) 190:307-337.

Persechini A, Moncrief ND, Kretsinger RH (1989) The EF-hand family of calcium-modulated proteins. Trends Neurosci 12:462-467.

Petralia RS, Wenthold RJ (1992) Light and electron immunocytochemical localization of AMPA-selective glutamate receptors in the rat brain. J Comp Neurol 318:329-354.

Reiner A, Medina L, Figueredo-Cardenas G, Anfinson S (1995) Brainstem motoneuron pools that are selectively resistant in amyotrophic lateral sclerosis are preferentially enriched in parvalbumin: evidence from monkey brainstem for a calcium-mediated mechanism in sporadic ALS. Exp Neurol 131:239-250.

Ren JQ, Aika Y, Heizmann CW, Kosaka T (1992) Quantitative analysis of neurons and glial cells in the rat somatosensory cortex with special reference to GABAergic neurons and parvalbumin-containing neurons. Exp Brain Res 92:1-14.

Ribak CE, Nitsch R, Seress L (1990) Proportion of parvalbumin-positive basket cells in the GABAergic innervation of pyramidal and granule cells of the rat hippocampal formation. J Comp Neurol 300:449-461.

Sato K, Kiyama H, Tohyama M (1993) The differential expression patterns of messenger RNAs encoding non- $N$-methyl-D-aspartate glutamate receptor subunits (GluR1-4) in the rat brain. Neuroscience 52:515-539.

Seeburg PH (1993) The Trends Neurosci/TiPS lecture. The molecular biology of mammalian glutamate receptor channels. Trends Neurosci 16:359-365.

Sloviter RS (1987) Decreased hippocampal inhibition and a selective loss of interneurons in experimental epilepsy. Science 235:73-76.

Sloviter RS (1989) Calcium-binding protein (calbindin- $\mathrm{D}_{28 \mathrm{k}}$ ) and parvalbumin immunocytochemistry: localization in the rat hippocampus with specific reference to the selective vulnerability of hippocampal neurons to seizure activity. J Comp Neurol 280:183-196.

Tölle TR, Berthele A, Zieglgänsberger W, Seeburg PH, Wisden W (1993) The differential expression of 16 NMDA and non-NMDA receptor 
subunits in the rat spinal cord and in periaqueductal gray. $\mathrm{J}$ Neurosci 13:5009-5028.

van Brederode JFM, Helliesen MK, Hendrickson AE (1991) Distribution of the calcium-binding proteins parvalbumin and calbindin-D28k in the sensorimotor cortex of the rat. Neuroscience 44:157-171.

Van Eldik LJ, Zendegui JG, Marshak DR, Watterson DM (1982) Calcium-binding proteins and the molecular basis of calcium action. Int Rev Cytol 77:1-61.

Waldvogel HJ, Faull RLM, Williams MN, Dragunow M (1991) Differential sensitivity of calbindin and parvalbumin immunoreactive cells in the striatum to excitotoxins. Brain Res 546:329-335.

Weiss JH, Koh J-Y, Baimbridge KG, Choi DW (1990) Cortical neurons containing somatostatin- or parvalbumin-like immunoreactivity are atypically vulnerable to excitotoxic injury in vitro. Neurology 40:1288-1292.

Weiss JH, Turetsky D, Wilke G, Choi DW (1994) AMPA/kainate receptor-mediated damage to NADPH-diaphorase-containing neurons is $\mathrm{Ca}^{2+}$ dependent. Neurosci Lett 167:93-96.

Wenthold RJ, Yokotani N, Doi K, Wada K (1992) Immunochemical characterization of the non-NMDA glutamate receptor using subunitspecific antibodies: evidence for a hetero-oligomeric structure in rat brain. J Biol Chem 267:501-507.

Westbrook GL (1994) Glutamate receptor update. Curr Opin Neurobiol 4:337-346. 